\title{
PERAN PEMERINTAH DALAM MENANGGULANGI RESIKO BENCANA BANJIR DI KABUPATEN KOLAKA UTARA
}

\author{
Vidia Reski Awalia1 ${ }^{1}$ Mappamiring², Andi Nuraeni Aksa² \\ ${ }_{1}^{1}$ Program Studi Ilmu Pemerintahan Fakultas Ilmu Sosial dan Ilmu Politik \\ Universitas Muhammadiyah Makassar \\ Jl Sultan Alauddin No 259 Makassar 90221 \\ vidia awalia@yahoo.com \\ ${ }^{2}$ Program Studi Ilmu Adiministrasi Negara Fakultas Ilmu Sosial dan Ilmu Politik \\ Universitas Muhammadiyah Makassar \\ Jl Sultan Alauddin No 259 Makassar 90221 \\ mappamiring@yahoo.com \& nuraeni aksa@yahoo.co.id
}

\begin{abstract}
Cope with disasters is an obligation for local governments as stakeholders in the Region. In anticipation of a disaster in order not to cause any material damage early anticipation of course required of local governments and communities in addition to the government setempat. Because community also has an important role taking part in the face of future disasters, so as to create a sense of security even though the area is categorized as prone to risk disaster. Based on this, researchers are encouraged to try to describe and explain the role of the government and society in tackling the risk of disaster in the village Tahibua. This research is a qualitative research. The results of this study indicate that the government's role in disaster relief in the Village Tahibua can be considered very good, because, based on the narrative of the people in the village Tahibua itself felt the programs that the government has carried out as well as the preparedness of intensified done well before they occur and when disaster.
\end{abstract}

Keywords: the role of government, disaster risk

\begin{abstract}
ABSTRAK
Menanggulangi bencana merupakan kewajiban bagi pemerintah daerah selaku stakeholders di Daerah. Dalam mengantisipasi setiap bencana agar tidak menimbulkan kerugian materiil tentunya dibutuhkan antisipasi sejak dini dari pemerintah daerah dan masyarakat setempat. Karena selain pemerintah masyarakat juga memiliki peranan penting ikut andil dalam menghadapi bencana yang akan terjadi, sehingga mampu tercipta rasa aman meski daerah tersebut termasuk kategori rawan resiko bencana. Berdasarkan hal tersebut, peneliti terdorong untuk mencoba menggambarkan dan menjelaskan tentang peran pemerintah dan masyarakat dalam menanggulangi resiko bencana di Desa Tahibua. Jenis penelitian ini adalah penelitian kualitatif. Hasil penelitian ini menunjukkan bahwa peran pemerintah dalam penanggulangan bencana di Desa Tahibua bisa dikategorikan sangat baik, karena berdasar dari penuturan masyarakat di Desa Tahibua itu sendiri yang merasakan program-program yang telah pemerintah laksanakan serta kesiapsiagaan yang sangat intensif dilakukan baik sebelum terjadi dan ketika terjadi bencana.
\end{abstract}

Kata kunci: peran pemerintah, resiko bencana 


\section{A. PENDAHULUAN}

Banjir merupakan luapan air yang melebihi tinggi muka air normal sehingga melimpas dari palung sungai yang menyebabkan genangan pada lahan rendah di sisi sungai. Lazimnya banjir disebabkan oleh curah hujan yang tinggi diatas normal. Akibatnya, sistem pengaliran air yang terdiri dari sungai dan anak sungai alamiah serta sistem saluran drainase dan kanal penampung banjir buatan yang ada tidak mampu menampung akumulasi air hujan sehingga meluap. Kemampuan/daya tampung sistem pengairan air dimaksud tidak selamanya sama, akan tetapi berubah akibat sedimentasi, penyempitan sungai akibat fenomena alam dan ulahmanusia, tersumbat sampah serta hambatan lainnya.

Bencana banjir hampir setiap musim melanda Indonesia. Berdasarkan nilai kerugian dan frekuensi kejadian bencana banjir terlihat adanya peningkatan yang cukup berarti. Kejadian bencana banjir sangat dipengaruhi oleh faktor alam berupa curah hujan yang diatas normal dan adanya pasang naik air laut. Disamping itu faktor ulah manusia berperan penting seperti penggunaan lahan yang tidak tepat (pemukiman di daerah bantaran sungai, di daerah resapan, penggundulan hutan), pembuangan sampah kedalam sungai, pembangunan pemukiman didaerah dataran banjir.

Penggundulan hutan di daerah tangkapan air hujan juga menyebabkan peningkatan debit banjir karena pasokan air masuk kedalam sistem aliran menjadi tinggi, melampaui kapasitas pengaliran dan menjadi pemicu terjadinya erosi pada lahan curam. Hal ini menyebabkan terjadinya sedimentasi sistem pengaliran air dam wadah air lainnya. Selain itu berkurangnya daerah resapan juga merupakan kontribusi terhadap meningkatnya debit banjir. Pada daerah pemukiman dimana telah padat dengan bangunan sehingga tingkat resapan air ke dalam tanah berkurang. Jika terjadi hujan dengan curah hujan yang tinggi sebagian besar air akan menjadi aliran air permukaan yang langsung masuk ke dalam sistem pengaliran air sehingga kapasitasnya terlampaui dan mengakibatkan banjir.

Disamping pemahaman bencana yang bertitik tolak berdasarkan keseimbangan semesta, terdapat pemahaman yang bertitik tolak berdasarkan keseimbangan lingkungan. Tidak dapat kita pungkiri bahwa manusia hidup berdampingan dan saling membutuhkan melalui interaksinya dengan alam. Interaksi ini sangat terapi dan tersistem sehingga secara keseluruhan berjalan sangat teratur. Namun dalam dalam perjalanannya manusia cenderung serakah, merusak dan menghancurkan alam yang pada akhirnya kerusakan/kehancuran alam tersebut ditimpahkan kepada generasi sesudahnya yaitu keturunan anak cucu mereka.

$$
\text { Peraturan Daerah Kabupaten }
$$

Kolaka Utara No. 5 Tahun 2010 Tentang Organisasi dan Tata Kerja Badan Penanggulangan Bencana Daerah. Sesuai dengan realitas yang terjadi di lapangan, penulis dapat mengutip dilatar belakang bahwa "peran pemerintah dalam menanggulangi resiko bencana banjir" masih berada pada tahap kurang aman, hal ini terjadinya banjir karena hujan yang terus menerus turun dan bertepatan dengan air pasang, tidak ada korban jiwa, dan pemerintah langsung turun ke lokasi untuk memberikan bantuan tanggap darurat terus melakukan pendataan untuk menghitung jumlah kerugian materil yang dialami masyarakat Tahibua.

Hal lain yang diharapkan dari peran pemerintah dalam menanggulangi resiko bencana di Desa Tahibua Kecamatan 
Tiwu Kabupaten Kolaka Utara bersikap tegas dan memberikan sanksi kepada para pelaku yang dengan sengaja merusak ekosistem alam, sehingga bisa memberikan efek jerah kepada pelaku. Dengan hal tersebut bisa meminimalisir terjadinya bencana alam yang tidak diharapkan bersama. Oleh karena itu, semuanya untuk kelangsungan anak cucu dimasa yang akan datang.

\section{B. TINJAUAN PUSTAKA \\ 1. Konsep Peran Pemerintah}

Peranan berasal dari kata peran yang berarti sesuatu yang menjadi bagian atau memegang pimpinan yang terutama. Peranan atau role juga diartikan sebagai suatu kelakuan yang diharapkan dari oknum dalam antar hubungan sosial tertentu yang berhubungan dengan status sosial tertentu. Melihat pengertian ini, jika dikaitkan dengan pengertian peranan dalam pemerintah Kecamatan adalah tugas dan wewenang pemerintah Kecamatan sesuai dengan tujuan yang ingin dicapai. Untuk itu supaya pemerintah dapat melaksanakan sesuai dengan tujuan yang telah ditetapkan maka harus menjalankan peranannya. Hal ini senada dengan apa yang dikemukakan oleh Soekanto (2002: 243) peranan adalah aspek dinamis dari kedudukan tertentu (status) apabila seseorang melaksanakan hak-hak tertentu serta kewajiban sesuai dengan kedudukannya maka ia dikatakan menjalankan peranannya.

Kurangnya pemahaman setiap pejabat pimpinan dalam suatu organisasi merupakan manajer sumber daya manusia. Artinya, para manajer ikut dan harus terlibat dalam mengambil berbagai langkah kegiatan manajemen sumber daya manusia, mulai dari perencanaan ketenagakerjaan hingga pensiunan pegawai.
Akan tetapi biasanya dalam suatu organisasi dibentuk suatu kerja yang melakukan kegiatan pengelolaan sumber daya manusia dan satuan kerja tersebutlah yang secara fungsional bertanggung jawab dalam melakukan berbagai kegiatan dan mengambil berbagai langkah dalam manajemen sumber daya manusia. Terdapat dua alasan kuat mengapa satuan kerja fungsional demikian perlu dibentuk. Pertama, meskipun bahwa setiap manajer yang bersangkutan diserahi tugas dan tanggung jawab melaksanakan kegiatankegiatan lain, baik yang sifatnya tugas pokok maupun tugas penunjang, sehingga perhatian utamanya ditujukan kepada tanggung jawab fungsional itu. Kedua, manajemen sumber daya manusia mutlak perlu ditangani secara profesional oleh tenaga-tenaga spesial karena hanya dengan demikianlah manajemen sumber daya manusia yang sangat kompleks itu dapat ditangani dengan baik. (Siagian, 2001:31).

Dari beberapa uraian di atas maka disimpulkan bahwa peranan merupakan perilaku, tugas yang besar pengaruhnya pada suatu peristiwa. sehingga dalam konteks pembahasan peranan dimaksudkan sebagai keterlibatan atau keikutsertaan secara aktif dalam suatu pencapaian yang dilakukan oleh individu atau kelompok terhadap penanggulangan bencana banjir di Kolaka Utara dalam rangka terwujudnya sebagai kota yang aman dan damai.

\section{a. Pemerintah Daerah}

$\begin{array}{ccc}\text { Pemerintah } & \text { adalah } & \text { sekumpulan } \\ \text { orang-orang } & \text { yang } & \text { mengelola }\end{array}$ kewenangan-kewenangan, melaksanakan kepemimpinan dan koordinasi pemerintahan serta pembangunan masyarakat dari lembaga-lembaga dimana mereka ditempatkan. Pemerintah dalam arti luas pemerintah didefinisikan sebagai Suatu bentuk organisasi yang 
bekerja dengan tugas menjalankan suatu sistem pemerintahan. Pemerintah dalam arti sempit didefinisikan sebagai Suatu badan persekumpulan yang memiliki kebijakan tersendiri untuk mengelola, serta mengatur jalannya suatu sistem pemerintahan.

Pada awal lahirnya pemerintahan adalah untuk menjaga suatu sistem ketertiban di dalam masyarakat, sehingga masyarakat tersebut bisa menjalankan kehidupan secara wajar. Seiring dengan perkembangan masyarakat modern yang ditandai dengan meningkatnya kebutuhan, peran pemerintah kemudian berubah menjadi melayani masyarakat. Pemerintah modern, pada hakekatnya adalah pelayanan kepada masyarakat. Pemerintah tidaklah diadakan untuk melayani diri sendiri, tetapi untuk melayani masyarakat, menciptakan kondisi yang memungkinkan setiap anggota untuk mengembangkan kemampuan dan kreatifitasnya demi mencapai kemajuan bersama.

Demikian dengan lahirnya pemerintahan dapat memberikan pemahaman terhadap kehadiran suatu pemerintahan merupakan manifestasi dari kehendak masyarakat yang bertujuan untuk berbuat baik bagi kepentingan masyarakat, bahkan Van Poelje (Hamdi, 1999:52) menegaskan bahwa pemerintahan dapat dipandang sebagai suatu ilmu yang mengajarkan bagaimana cara terbaik dalam mengarahkan dan memimpin pelayanan umum. Defenisi ini menggambarkan bahwa pemerintahan sebagai suatu ilmu yang mencakup 2 (dua) unsur utama yaitu: pertama, masalah bagaimana sebaiknya pelayanan umum dikelola, jadi termasuk seluruh permasalahan pelayanan umum, dilihat dan dimengerti dari sudut kemanusian. Kedua, bagaimana sebaiknya memimpin pelayanan umum, jadi tidak hanya mencakup masalah pendekatan yaitu bagaimana sebaiknya mendekati masyarakat oleh para pengurus, dengan pendekatan terbaik, masalah hubungan antara birokrasi dengan masyarakat, dan permasalahan psikologi sosial.

Dari uraian tersebut menjelaskan bahwa suatu pemerintahan hadir karena adanya suatu komitmen bersama yang terjadi antara pemerintah dengan rakyatnya sebagai pihak yang diperintah dalam suatu posisi dan peran, yang mana komitmen tersebut hanya dapat dipegang apabila rakyat dapat merasa bahwa pemerintah itu memang diperlukan untuk melindungi, memberdayakan dan mensejahterakan rakyat. Menurut Ndraha (2000 : 70) mengatakan bahwa pemerintah memegang tanggung jawab atas nama rakyat.

\section{b. Tugas Pemerintah}

Terkait tugas pemerintah menurut Kaufman (Thoha, 1995:101) menyatakan bahwa tugas pemerintah adalah untuk melayani dan mengatur masyarakat, kemudian dijelaskan lebih lanjut bahwa tugas pelayanan lebih menekankan upaya mendahulukan kepentingan umum, mempermudah urusan publik dan memberikan kepuasan kepada publik, sedangkan tugas mengatur lebih menekankan kekuasaan power yang melekat pada posisi jabatan birokrasi.

Sementara Menurut Rasyid (2000 : 13) tugas pemerintah secara umum berkaitan dengan tugas-tugas pokok pemerintah yaitu:

(1) Menjamin keamanan negara dari segala kemungkinan serangan dari luar, dan menjaga agar tidak terjadi pemberontakan dari dalam yang dapat menggulingkan pemerintahan yang sah melalui cara-cara kekerasan;

(2) Memelihara ketertiban dengan mencegah terjadinya perselisihan diantara warga masyarakat, 
menjamin agar perubahan apapun yang terjadi di dalam masyarakat dapat berlangsung secara damai;

(3) Menjamin diterapkannya perlakuan yang adil kepada warga masyarakat tanpa membedakan status apapun yang melatarbelakangi keberadaan mereka;

(4) Melakukan pekerjaan umum dan memberikan pelayanan dalam bidang-bidang yang tidak mungkin dikerjakan oleh lembaga non pemerintahan, atau yang akan lebih baik jika dikerjakan oleh pemerintah;

(5) Melakukan upaya-upaya untuk meningkatkan kesejahteraan sosial, misalnya : membantu orang miskin dan memelihara orang cacat, jompo dan anak terlantar, menampung serta menyalurkan para gelandangan ke sektor kegiatan yang produktif, dan semacamnya;

(6) Menerapkan kebijakan ekonomi yang menguntungkan masyarakat luas, seperti mengendalikan laju inflasi, mendorong penciptaan lapangan kerja baru, memajukan perdagangan domestic dengan antar bangsa, serta kebijakan lain yang secara langsung menjamin peningkatan ketahanan ekonomi negara dan masyarakat;

(7) Menerapkan kebijakan untuk memelihara sumber daya alam dan lingkungan hidup, seperti air, tanah dan hutan.

\section{c. Fungsi Pemerintah}

Menurut Ndraha (2001 : 85) fungsi pemerintahan tersebut ada 2 (dua) macam fungsi, yaitu: (1) Pemerintah mempunyai fungsi primer atau fungsi pelayanan (service), sebagai provider jasa publik yang baik diprivatisasikan dan layanan civil termasuk layanan birokrasi; (2) Pemerintah mempunyai fungsi sekunder atau fungsi pemberdayaan, sebagai penyelenggara pembangunan dan melakukan program pemberdayaan. Dengan begitu luas tugas dan fungsi pemerintahan, menyebabkan pemerintah harus memikul tanggung jawab yang sangat besar. Dalam mengembangkan tugas yang berat itu, selain diperlukan sumber daya, dukungan lingkungan, dibutuhkan institusi yang kuat didukung oleh aparat yang memiliki perilaku yang sesuai dengan nilai dan norma yang berlaku didalam masyarakat dan pemerintahan. Langkah ini perlu dilakukan oleh pemerintah, mengingat dimasa mendatang perubahan-perubahan yang terjadi didalam masyarakat akan semakin menambah pengetahuan masyarakat untuk mencermati segala aktivitas pemerintahan dalam hubungannya dengan pemberian pelayanan kepada masyarakat.

\section{d. Pengertian Pemerintah Daerah}

Pemerintah daearah adalah Gubernur, Bupati, atau Walikota, dan perangkat daerah sebagai unsur penyelenggara pemerintahan daerah. Dengan demikian peran pemerintah daerah adalah segala sesuatu yang dilakukan dalam bentuk cara tindak baik dalam rangka melaksanakan otonomi daerah untuk mengatur dan mengurus sendiri urusan pemerintahan dan kepentingan masyarakat setempat sesuai dengan peraturan perundang-undangan.

Defenisi pemerintah daerah berdasarkan UU No 32 Tahun 2004 tentang pemerintahan daerah pasal 1 ayat 2, adalah sebagai berikut: "Pemerintah Daerah adalah penyelenggara urusan pemerintahan oleh pemerintahan daerah dan DPRD menurut asas otonomi dan tugas pembantuan dengan prinsip otonomi yang seluas-luasnya dalam sistem dan prinsip Negara Kesatuan Republik Indonesia sebagaimana dimaksud dalam Undang-Undang Dasar Negara Republik Indonesia Tahun 1945. 
Berdasarkan UU No. 32 tahun 2004 tentang pemerintahan daerah adalah penyelenggaraan urusan pemerintah daerah dan DPRD menurut asas otonomi dan tugas pembantuan dan unsur penyelenggaraan pemerintahan daerah adalah gubernur, bupati, walikota dan perangkat daerah.

Penyelenggaraan pemerintahan daerah disesuaikan dengan amanat Undang-Undang Dasar Negara Republik Indonesia Tahun 1945, yaitu pemerintahan daerah, yang mengatur dan mengurus sendiri urusan pemerintahan menurut asas otonomi dan tugas pembantuan, diarahkan untuk mempercepat terwujudnya kesejahteraan masyarakat melalui peningkatan, pelayanan, pemberdayaan, peran masyarakat, serta peningkatan daya saing daerah dengan memperhatikan prinsip demokrasi, pemerataan, keadilan, keistimewaan dan kekhususan suatu daerah dalam sistem Negara Kesatuan Republik Indonesia. Pemerintahan daerah dalam rangka meningkatan efisiensi dan efektivitas penyelenggaraan otonomi daerah, perlu memperhatikan hubungan antar susunan pemerintahan dan antar pemerintahan daerah, potensi dan keanekaragaman daerah.

\section{Konsep Bencana}

Menurut Undang-undang No. 24 Tahun 2007, bencana adalah peristiwa atau rangkaian peristiwa yang mengancam dan mengganggu kehidupan dan penghidupan masyarakat yang disebabkan, baik oleh faktor alam atau faktor non alam maupun faktor manusia sehingga mengakibatkan timbulnya korban jiwa manusia, kerusakan lingkungan, kerugian harta benda, dan dampak psikologis.

\section{a. Jenis-Jenis Bencana}

Jenis-jenis bencana menurut Undang-undang No. 24 Tahun 2007 tentang penanggulangan bencana, yaitu: a) Bencana alam adalah bencana yang diakibatkan oleh peristiwa atau serangkaian peristiwa yang disebabkan oleh alam antara lain berupa gempa bumi, tsunami, gunung meletus, banjir, kekeringan, angin topan, dan tanah longsor;

b) Bencana non alam adalah bencana yang diakibatkan oleh peristiwa atau rangkaian peristiwa non alam antara lain berupa gagal teknologi,gagal modernisasi. dan wabah penyakit;

c) Bencana sosial adalah bencana yang diakibatkan oleh peristiwa atau rangkaian peristiwa yang disebabkan oleh manusia yang meliputi konflik sosial antar kelompok atau antar komunitas masyarakat.

\section{b. Faktor Penyebab Terjadinya Bencana}

Terdapat 3 (tiga) faktor penyebab terjadinya bencana, yaitu : (1) Faktor alam (natural disaster) karena fenomena alam dan tanpa ada campur tangan manusia. (2) Faktor non-alam (nonnatural disaster) yaitu bukan karena fenomena alam dan juga bukan akibat perbuatan manusia, dan (3) Faktor sosial/manusia (man-made disaster) yang murni akibat perbuatan manusia, misalnya konflik horizontal, konflik vertikal, dan terorisme.

\section{c. Upaya-upaya Penanggulangan Dan Pencegahan Bencana}

Upaya-upaya penanggulangan bencana yaitu: (1) Mitigas dapat juga diartikan sebagai penjinak bencana alam, dan pada prinsipnya mitigasi adalah usaha-usaha baik bersifat persiapan fisik, maupun non-fisik dalam menghadapi bencana alam. Persiapan fisik dapat berupa penataan ruang kawasan bencana dan kode bangunan, sedangkan persiapan non-fisik dapat berupa pendidikan tentang bencana alam; (2) Menempatkan Korban di Suatu Tempat yang Aman adalah hal yang mutlak diperlukan. Sesuai 
dengan deklarasi Hyogo yang ditetapkan pada Konferensi Dunia tentang Pengurangan Bencana, di Kobe, Jepang, pertengahan Januari 2005, menyatakan bahwa: "Negara-negara mempunyai tanggung jawab utama untuk melindungi orang-orang dan harta benda yang berada dalam wilayah kewenangan dan dari ancaman dengan memberikan prioritas yang tinggi kepada pengurangan resiko bencana dalam kebijakan nasional, sesuai dengan kemampuan mereka dan sumber daya yang tersedia kepada mereka"; (3) Membentuk Tim Penanggulangan Bencana; (4) Memberikan Penyuluhanpenyuluhan; (5) Merelokasi Korban Secara Bertahap.

Upaya-upaya pencegahan ancaman alam yaitu: (1) Membuat pos peringatan bencana; (2) Membiasakan hidup tertib dan Disiplin; dan (3) Memberikan Pendidikan tentang Lingkungan Hidup.

\section{METODE PENELITIAN}

Penelitian ini dilakukan di Kantor Badan Penanggulangan Bencana Daerah dan di Desa Tahibua Kabupaten Kolaka Utara. Jenis penelitian yang digunakan adalah kualitatif, dan metode penelitian yang digunakan adalah observasi, wawancara, dan dokumentasi. Pengumpulan data dilakukan secara triangulasi (gabungan). Informan dalam penelitian ini yakni sebagai berikut: Kepala dinas badan penanggulanagan bencana daerah, Kepala Kecamatan Tiwu, Kepala Desa Tahibua, masyarakat korban bencana. Data yang dikumpulkan dalam berbentuk data primer dan data sekunder.

\section{HASIL DAN PEMBAHASAN}

\section{Peran Pemerintah Dalam Menanggulangi Resiko Bencana Banjir Di Desa Tahibua Kecamatan Tiwu Kabupaten Kolaka Utara}

Pemerintah harus menpunyai kemampuan yang cukup besar untuk mengontrol setiap bencana yang terjadi. Kemampuan itu meliputi perencanaan dan persiapan respons bencana, bantuan koordinasi, kebijakan rekontruksi dan mengatasi masalah populasi. Pemerintah dengan sebuah pengembangan program manajemen bencana dapat melakukan koordinasi yang baik. Berdasarkan pada hukum kemanusiaan internasional, pemerintah nasional merupakan pihak utama yang harus merespon bencana alam.

Hal ini mengacu pada Pasal 3 Undang-undang Nomor 24 Tahun 2007 tentang Penanggulangan Bencana menyatakan bahwa penanggulangan bencana harus didasarkan pada azas atau prinsip-prinsip utama anatara lain: kemanusiaan, keadilan, kesamaan kedudukan dalam hukum dan pemerintahan, keseimbangan, keselarasan dan keserasian, ketertiban dan kepastian hukum, kebersamaan, kelestarian lingkungan hidup, ilmu pengetahuan dan teknologi. Selain itu, penanggulanan bencana juga harus di dasarkan pada prinsip-prinsip praktis sebagai berikut: cepat dan tepat, prioritas, koordinasi dan keterpaduan, berdaya guna dan berhasil guna, transparansi dan akuntabilitas, kemitraan, pemberdayaan, non-diskriminasi, dan non-proselitasi. sebagaimana wawancara dengan ketua BPBD Kabupaten Kolaka Utara sebagai berikut :

"Pada prinsipnya tujuan utama kita adalah melakukan pelayanan kepada masyarakat. jadi pelayanan untuk sementara yang kita lakukan ketika terjadi bencana terlebih dahulu kita menurunkan personil untuk melihat kondisinya seperti apa yang terjadi di lapangan". (wawancara MU)

Wawancara dengan kepala BPBD menjelaskan tentang bagaimana tindakan 
yang dilakukan ketika terjadi bencana dengan melayani masyarakat, sehingga ketika terjadi bencana alam, BPBD langsung menurunkan anggotanya ke lokasi bencana dan mengeksekusi langsung korban di lapangan.

Penuturan diatas mengindikasikan bagaiamana peran kepala badan dalam melaksanakan tugasnya dan bertindak sebagaimana seharusnya seorang pelayan masyarakat yang bertanggung jawab dalam melaksanakan tugas.

Sebagaimana yang diungkapkan salah satu anggota BPBD sebagai berikut:

"setelah di lapangan kami dengan dinas-dinas terkait langsung menjalankan tugas masingmasing sesuai perencanaan, dimana dalam seperti ini kegiatan kita butuh perangkar dari dinas sosial untuk mensuplai logistik seperti beras, pakaian. Supaya kita langsung berikan kepada masyarakat". (wawancara GU)

Dari pernyataan salah satu anggota BPBD di atas memberikan keterangan bahwa ketika berada di lokasi para anggota melaksanakan tugasnya masingmasing sesuai dengan rencana. Seperti, pemberian logistik dan barang keperluan pokok. Akan tetapi dalam kegiatan penanggulangan bencana dibutuhkan kerjasama dengan dinas pemerintahan yang lain seperti dinas sosial yang merupakan naungan BPBD itu sendiri.

"Di lokasi kalau sifatnya itu direhabilitasi maka itu akan langsung diadakan penanganan secara tanggap darurat sementara untuk mengamankan korban sampai betul-betul aman."(wawancara GU ).

Dari pernyataan di atas penulis mendefinisikan bahwa salah satu yang biasa dilakukan dalam penanganan korban bencana yaitu rehabilitasi dengan penanganan memberikan bantuan dan mengeksekusi korban dengan melakukan penanganan tanggap darurat dengan penanganan ekstra sehingga korban merasa aman, ini merupakan salah satu prinsip tugas dari organisasi pemerintahan yang bekerja untuk kemanusiaan yang memperhatikan keselamatan bagi orang banyak.

\section{Korabolasi pemerintah Daerah dengan masyarakat dalam Menanggulangi Bencana Banjir}

Dalam menanggulangi atau mengurangi resiko bencana, tidak cukup jika hanya dilakukan oleh suatu kelompok saja. Namun juga dibutuhkan kerjasama dan keterlibatan pro aktif dari banyak pihak, baik itu dari pemerintah, kelompok atau organisasi masyarakat, pengusaha dan masyarakat sipil. Selain itu, dibutuhkan pula manajemen bencana yang baik dari kerjasama banyak pihak tersebut. Jika kerjasamanya berjalan dengan baik, maka manajemen bencananya juga akan berjalan dengan baik dan sukses mengurangi resiko bencana. Uohan Minnie, 2010).

Untuk itu masyarakat pun memiliki andil dalam penanganan bencana, peran masyarakat menjadi elemen yang paling penting karena kekuatan pemerintah semata sangatlah kecil jika dibandingkan dengan tantangan yang begitu besar. Peran masyarakat dalam penanganan bencana dapat diwujudkan dalam beberapa bentuk: relawan lapangan dengan menyumbangkan tenaga dan keahlian, mobilisasi dana, dan akses fasilitas.

Terkait tentang peran serta masyarakat dalam penanggulangan bencana, seperti wawancara dengan kepala Desa Tahibua sebagai berikut :

"Alhamdulillah, selama ini bagus karena sudah jauh sebelumnya kita sudah memberikan sosialisasi pemahaman tentang 
kebencanaan dan pada saat terjadi bencana Alhamdulillah masyarakat juga dengan pemerintah serentak membantu keluarga yang terkena bencana itu". (wawancara YU)

Hasil wawancara dengan Kepala Desa Tahibua mengatakan bahwa masyarakat Desa Tahibua telah bekerja sama dengan baik. Ini terlihat ketika terjadi bencana masyarakat bersama pemerintah bahu-membahu membantu warga lain yang terkena dampak resiko bencana. Bekal tersebut diperoleh dari hasil sosialisasi pemerintah untuk mengantisipasi datangnya banjir, sehingga ketika terjadi bencana masyarakat sudah tahu langkah yang akan dilakukan untuk menyelamatkan diri sampai menolong warga lain yang terkena dampak bencana.

Wawancara dengan salah satu masyarakat Desa Tahibua mengatakan sebagai berikut:

"Iya, kami masyarakat di sini selalu dibekali pengetahuan dan juga peringatan ketika akan memasuki musim hujan. Kami diminta untuk selalu waspada khususnya yang tinggal di dekat sungai." (wawancara SH).

Penuturan diatas mengindikasikan bahwa masyarakat telah menerima dengan baik pengetahuan dan himbauan yang disosialisasikan oleh pemerintah sehingga masyarakat telah mengantisipasi segala kemungkinan yang bisa terjadi. Ini menindikasikan bahwa peran pemerintah dalam melaksanakan konsep manajemen penanggulangan bencana yang bertujuan untuk memberdayakan masyarakat. Wawancara dengan kepala Desa Tahibua sebagai berikut:

\footnotetext{
"Masyarakat disini telah diantisipasi dan dilibatkan untuk bekerjasama dengan pemerintah
}

yaitu BPBD untuk yang memonitoring dan diberikan sosialisasi kepada masyarakat dari tim untuk tentang antisipasi masalah bencana. "(wawancara $Y U)$.

Pernyataan Kepala Desa diatas mengungkapkan kerjasama yang dibangun antara pemerintah untuk memberdayakan masyarakat dalam mengantisipasi dan mencegah terjadinya kerugian akibat banjir, sehingga dalam mengantisipasi semuanya telah dilakukan sosialisasi prabencana. Pemerintah telah melaksanakan fungsi kontrol dan fungsi antisipasi, merupakan salah satu prinsip dari penanggulangan bencana. Wawancara dengan salah satu masyarakat sebagai berikut:

"Kami bersama warga lainnya membantu membenahi fasilitas yang rusak akibat terjangan banjir, seperti rumah-rumah warga, jalan, jembatan sehingga dapat dipergunakan kembali setelah terjadi sehingga tidak butuh waktu lama untuk tinggal di pengungsian dan pasokan bantuan darurat bisa lancar ke lokasi."(wawancara KA).

Pemulihan darurat dengan operasi tanggap darurat pada aspek pemulihan darurat berupa perbaikan prasarana dan sarana vital seperti: jalan, jembatan, pelabuhan, Bandar udara dan lain-lain. Hal ini dapat dilakukan sejak sesaat setelah kejadian bencana. Tujuannya adalah untuk kelancaran pasokan bantuan darurat, dukungan ketersediaan bahan bakar dan kebutuhan dasar lainnya serta untuk mempercepat normalisasi kehidupan sosial ekonomi masyarakat. Pemulihan darurat mempunyai pengertian asal berfungsi atau dapat berfungsi meskipun dalam kondisi minimal. Ini dimaksudkan untuk mengkondisikan masyarakat agar dapat 
mulai menjalani kehidupan sehari-hari. Wawancara dengan salah satu kepala dusun yang wilayahnya juga terkena bencana alam sebagai berikut :

"Saya sangat bersyukur karena kita disini sudah mengantisipasi meski ketika terjadi bencana alam ada himbauan dari pemerintah setempat, akan tetapi masyarakat sudah tahu apa yang harus dilakukan dari bekal yang mereka dapatkan sebelumnya. "(wawancara AR).

Pemerintah dapat dikatakan telah berhasil dalam memberdayakan masyarakat. seperti penanggulangan tanggap darurat yang meliputi. Pengkajian secara cepat dan tepat terhadap lokasi, kerusakan, kerugian, dan sumber daya, penyelamatan dan evakuasi masyarakat terkena banjir. (Nurjanah, 2010: 99).

Lebih lanjut Pemerintah sebagai pelayan masyarakat yang memiliki kewajiban dalam mengatasi banjir, melakukan hal-hal yang dapat mengurangi banjir seperti, membuat waduk yang dapat menampung air hujan, dan menyediakan tempat sampah agar masyarakat tidak membuang sampah sembarangan. Dan masyarakat juga harus mempunyai kesadaran untuk menjaga lingkungan. Pemerintah dengan masyarakat dapat bekerjasama untuk menanggulangi banjir dan melakukan kembali penghijauan atau penanaman pohon disekitar lahan kosong.

Langkah yang ditempuh sebagai bentuk evaluasi terkait persoalan bencana alam yang terjadi di Indonesia. Lebih lanjut kebijakan tersebut dituangkan dalam berbagai peraturan perundangan dan program penanggulangan bencana. Secara umum kebijakan nasional penanggulangan bencana dituangkan dalam Undangundang Nomor 24 Tahun 2007 tentang
Penanggulangan Bencana, Peraturan Pemerintah Nomor 21 Tahun 2008 tentang

Penyelenggaraan

Penanggulangan Bencana, Peraturan Pemerintah Nomor 22 Tahun 2008 tentang Pendanaan dan Pengelolaan Bantuan Bencana, Peraturan Pemerintah Nomor 23 Tahun 2008 tentang Peran Serta Lembaga Internasional dan Lembaga Asing Non-Pemerintah dalam Penanggulangan Bencana, serta Peraturan Presiden Nomor 8 Tahun 2008 tentang Badan Nasional Penanggulangan Bencana.

\section{E. PENUTUP}

Peran pemerintah dalam menanggulangi resiko bencana banjir di Desa Tahibua Kecamatan Tiwu Kabupaten Kolaka Utara sudah baik, ini terlihat dalam peranan ketua BPBD dalam penerapan prinsip-prinsip manajemen bencana yang baik, yaitu cepat dan tepat. Penanggulangan bencana dilakukan secara cepat dan tepat sesuai dengan tuntutan keadaan. Adanya koordinasi yang baik sebagai upaya penanggulangan bencana yang didasarkan pada koordinasi yang baik dan saling mendukung, serta dalam penanggulangan bencana harus melibatkan berbagai pihak secara seimbang.

Upaya Oranisasi BPBD yang selalu berupaya untuk melakukan penyuluhan kepada masyarakat sebelum terjadi bencana adalah analisis upaya yang nyata dilakukan oleh pemerintah.

Selanjutnya kerjasama antara pemerintah dan masyarakat dalam menanggulangi bencana banjir sudah ada yaitu sebagaiaman masyarakat ikut berpartisipasi dalam ikut penyuluhan yang dilakukan oleh pihak BPBD, masyarakat juga ikut dalam menjaga beronjong yang telah dibangun sebagai penopang tebing sungai agar tidak terjadi pengikisan yang dapat menyebabkan 
terjadinya erosi. Masyarakat juga selalu tanggap dalam menyikapi imbauan dari pemerintah seperti peringatan prabencana dan keikutsertaan dalam pengadaan logistik bahan pembuatan beronjong.

Mengurangi resiko banjir yang meliputi pengenalan dan pemantauan resiko bencana sejak dini, perencenaan partisipatif penanggulangan bencana, pengembangan budaya sadar bencana, peningkatan komitmen terhadap pelaku penanggulangan bencana itu sendiri.

Proteksi dini dilakukan untuk melindugi masyarakat dari dampak bencana. Perlindungan masyarakat di Desa Tahibua yaitu dengan cara penanganan tanggap darurat yang dilakukan segera setalah kejadian bencana, untuk menanggulangi dampak bencana. Tanggap darurat ditujukan agar masyarakat/korban bencana tetap mempertahankan hidup meskipun dalam kondisi darurat. Dimana dalam penanganan bencana tersebut BPBD dalam operasi melibatkan banyak instansi lain seperti dinas sosial yang terkait baik dari segi sumbangsi tenaga dan materi.

Pemulihan kondisi dari dampak bencana di Desa Tahibua kemarin telah terlaksana seperti pembangunan kembali rumah-rumah korban banjir serta pemasangan beronjong bagi sungai yang ada yang bertujuan agar dapat mencegah terjadinya erosi di tebing sungai yang dapat menimbulkan kerugian bagi masyarakat sekitar. Kegiatan ini dilakukan sejak proses penilaian kerusakan dan kerugian, perencanaan, pelaksanaan, pemantauan dan evaluasi pelaksanaan kegiatan rehabilitasi dan rekonstruksi serta pengawasannya yang didukung pendanaan secara memadai.

Adapu yang menjadi saran dari hasil penelitian ini yakni sebagai berikut:

1. Khusus pemerintah daerah atau bupati sebaiknya mengupayakan agar segera membuat Perda tentang tata kerja organisasi BPBD agar tidak terlalu fokus pada keputusan pemerintah pusat mengingat setiap daerah berbeda kondisi dan potensi bahaya bencana alam yang bisa terjadi;

2. Sebaiknya pemerintah segera mencari solusi bagi masyarakat yang sering melakukan penebangan pohon sebelum terjadi penebangan yang meluas sekitar desa yang dapat berdampak bagi masyarakat di Desa Tahibua.

\section{DAFTAR PUSTAKA}

Kaufman \& Rasyid, 2011. Tugas dan Fungsi Pemerintah (2 frameit. blogspot.com/2011/11/tugas dan fungsi pemerintah.html).

Nurjanna DKK., 2012. Manajemen Bencana, Alfabeta, Bandung.

Soerjono, Soekanto. 2002. Sosiologi Suatu Pengantar. Rajawali Jakarta.

Sugiono. 2007. Metode Penelitian Kualitatif dan Kuantitatif, $R \& D$. Bandung: Alfaeta

Madani, Muhlis DKK.,2012. Pedoman Penulisan Proposal Penelitian dan Skripsi. Makassar.

Ahyudin,2005. Peran Masyarakat dalam

Penanggulangan

Bencana.

Disampaikan pada focus-focus Group Discussion Masyarakat Penanggulangan Bencana Indonesia ( MPBI). Di Hotel Bidakara Jakarta.17 Maret 2005. (http://acccountability humanitarian forum Indonesia).

Staf Ahli Mentri Bidang Dampak Sosial, 2008. Pemberdayaan Peran Masyarakat Dalam Penanggulangan Bencana Alam. (http://www.scribd.com/doc/1565 42086/pemberdayaan-peranmasyarakat-dalampenanggulangan-bencana-alam). 
Vol. V No. 2 Oktober 2015

\section{Dokumen :}

UU No 32 Tahun 2004 Tentang Pemerintahan Daerah Pasal 1 ayat 2.

UU No 24 Tahun 2007 Tentang Penanggulangan Bencana.

Peraturan Presiden No 8 Tahun 2008 Tentang Badan Nasional Penanggulangan Bencana.

Peraturan Daerah Kabupaten Kolaka Utara Nomor 5 Tahun 2010 Tentang Tata Kerja Badan Penanggulangan Bencana Daerah.

Peraturan Pemerintah Nomor 21 Tahun 2008 tentang Penyelenggaraan Penanggulangan Bencana. 